\title{
Atividades educativas com idosos adscritos a uma unidade de saúde da família: relato de experiência
}

\author{
Vanessa de Souza Amaral, Deíse Moura de Oliveira, Rafaela Magalhães Fernandes Saltarelli
}

\begin{abstract}
Resumo
A educação em saúde constitui uma importante ferramenta que o enfermeiro e demais profissionais da equipe de saúde se utilizam para atuar na promoção da saúde de indivíduos e coletividades. A prática educativa deve perpassar as ações realizadas neste setor, em especial na Atenção Básica, por estar próxima da população, viabilizar a construção do vinculo, da co-responsabilização e da autonomia para o autocuidado. Além disso, possibilita atuar sobre os determinantes sociais da saúde, se ancorando na identidade cultural do território para intervir sobre as questões de saúde. Relatar atividades educativas realizadas durante o Estágio Supervisionado de Enfermagem em Saúde Coletiva com idosos adscritos a uma unidade de saúde da família de Viçosa. Trata-se de um relato de experiência discente. A mesma ocorreu entre abril e junho de 2016, tendo como estratégia metodológica a oficina educativa, por meio da qual os participantes foram conduzidos a refletir sobre a co-responsabilização no cuidado à saúde. Foram realizadas seis oficinas com os seguintes temas, respectivamente: os conceitos de saúde, a prevenção, o autocuidado, o baú de recordações, o ambiente e a saúde e a colcha de retalhos. Cabe ressaltar que tais idosos já possuíam vínculo anteriormente às ações realizadas, pois participam há cerca de cinco anos da caminhada que acontece na praça do bairro três vezes por semana. As atividades contaram com a participação ativa dos idosos, que tinham como fator potencializador o fato de já se conhecerem. Ao discutir sobre os conceitos de saúde foram evidentes as raízes do modelo biomédico, possibilitando que a oficina trouxesse à tona um novo olhar em relação à importância da prevenção e do autocuidado, desdobrando-se no segundo tema trabalhado. Na construção do báu de recordações cada participante contribuiu com sua experiência no cuidar, emergindo a compreensão de que todos os seres humanos trazem consigo uma bagagem que não pode ser desconsiderada no cuidado de si e do outro. A ligação direta do ambiente com o processo saúde/doença foi debatida ao ser construída pelo grupo a história do bairro, refletindo as melhorias na saúde e os desafios enfrentados com relação ao ambiente em que vivem. De forma dinâmica, a colcha de retalhos apresentou ao grupo a diversidade de fatores que compõem o processo saúde-doença-cuidado, reafirmando a co-responsabilização para a promoção da saúde e do bem-estar individual e da comunidade. Evidencia-se a importância da graduação em saúde oportunizar a vivência de práticas que qualificam o discente para atuar como educador em saúde no SUS. Considerando a mudança do perfil demográfico da população, a experiência ora relatada reitera a necessidade de ampliar práticas de promoção da saúde junto às pessoas idosas, considerando ser este um público expressivo no cotidiano dos serviços de saúde.
\end{abstract}

Descritores: Educação em Saúde; Saúde da Família; Saúde do Idoso. 